\title{
Global Media and Foreign Culture: A Sociological Analysis of Tribal Community in Dera Ghazi Khan, Punjab-Pakistan
}

\author{
Muhammad Adeel Kamran ${ }^{1}$, Mazhar Hussain Bhutta², Tahira Shamshad ${ }^{3}$, Muhammad Nadir \\ Shahzad ${ }^{1}$ \\ ${ }^{1,4} \mathrm{PhD}$ Scholar, Department of Sociology, PMAS Arid Agriculture University Rawalpindi-Pakistan \\ ${ }^{2}$ Assistant Professor, Department of Sociology, PMAS Arid Agriculture University Rawalpindi-Pakistan \\ ${ }^{3}$ Lecturer, Department of Sociology Ghazi University Dera Ghazi Khan-Pakistan
}

\section{ABSTRACT}

Usage of global media has been increasing in the modern world. It has also impact on cultural traits, societal values, and cultural identity. The present study examined the extent and nature of the usage of global media and the level of adoption of foreign culture in tribal community of Dera Ghazi Khan, Punjab province-Pakistan. Global media includes radio, satellite TV and internet. Foreign culture is operationalized as foreign language, dress, and food. The sample of 420 respondents was selected from the Tehsil Koh-e-Suleman (District Dera Ghazi Khan) through Multistage sampling technique. Spearmen correlation was used to examine the relationship between the usage of global media and adoption of foreign culture among the respondents. The results showed that global media has significant relationship with foreign culture e.g. foreign language $(\mathrm{P}=.003)$, foreign dress $(\mathrm{P}=.026)$ and foreign food $(\mathrm{P}=.000)$. In nutshell, it is concluded that technological development has impact on the cultural traits, societal values, and social relationship of the tribal people of Pakistan. Research implications of the investigation are also discussed.

Key Words: Global media, tribal cultural values, foreign cultural traits, Dera Ghazi Khan

Article Received: 18 October 2020, Revised: 3 November 2020, Accepted: 24 December 2020

\section{INTRODUCTION}

The general belief about globalization is that it is a new phenomenon caused by the recent technological developments, especially in the areas of communication and travel, which are associated with "a shrinking" world of distances, accelerated "speed" of cross-border flows, and the emergence of a global economy (Appadurai, 1990). The cross-border flows of information and communication are known as global media and it includes different technologies such as radio, satellite TV and internet. The revolution in communication has recently triggered social changes. Computer technology has enabled people to communicate fastlyright across the globe via e-mail. The planet has shrunk to what is sometimes denoted as the 'global village'. To promote this development of communications, a language in which correspondence could take place had to be used (Sultana, 2007).

Ahuja and Batra (1978), explained that, the communication media technology is rapidly changing culture by using modern mass media like Newspaper, Radio, Films and Television in one way. Later, satellite communications made the world's global village particularly through DTH TV and the Internet. The broadcast media Radio and DTH TV delivers the messages to millions of people simultaneously by wiping out the geographical and social barriers of communication. To receive the message, only one must have Radio and Television set.

Communication offers the connectivity structure for already gigantic and yet rising flow of technology in cultural industries, ruled by the United 
States(Schiller, 1969). In third world countries,international cultural goods meet local audiences via satellite television stations and other media networks, likeinternet.Communication plays a decisive role in shaping the culture and area of culture includes systems of beliefs and behaviors and is made by history (Castells, 2001). Culture is an amalgamation of human activities from a social perspectivecomprising individual representations of their selves and relationships(Roosens, 1995). Hofstede (1984) described culture as collective mental programming that differentiates the followers of one community from another. Further culture is not transmitted genetically, so for acquiring culture, a person has to be in the right place at the right time (Cleveland\& Laroche, 2007).

Cultural globalization can be measured by consuming mass media products imported from abroad like international television programs, movies, books and music (Kluver \& Fu, 2004). Experience of mixtures between a rich foreign culture and traditional culture can endanger cultural uniqueness and thus cause epistemic certainty and security needs (Morris, Mok, \& Mor, 2011).

\section{OBJECTIVES OF STUDY}

1. To assess the relationship between usage of global media and adoption of foreign culture in tribal community of Dera Ghazi Khan.

\section{REVIEW OF LIRERATURE}

The people are not only the objects who are influenced or victimized but they are the subjects have choice and power to either accept or reject the change, influence and effects of globalization. People are helped to connect closely with the advancement of technology which is part and product of globalization. There seems fine tuning between the sense of togetherness and diversity (Wang, 2007).
Verma (2008) stated that BUXA tribe resided in Uttrakhand state, is an ancient tribe because of its traditions. They worship natural things like river, Earth, hills, sun, moon and powerful animals. As like other tribal communities of the world, the use of media and technology is the cause of their fondness towards other cultures. They are leaving their traits and they have got political and administrative positions in their region, which shows that a conservative and primitive cultural people are going to rule the area, which is a big achievement for them. He called this change as global social change which is affecting all the societies of the world.

Qamar, Asim, Shawar, and Zafar (2012) found that cable television is an important source promoting cultural diffusion in Pakistan. Satellite channels and TV programs were not only affecting the social and psychological development of youth but also their dressing, language, household living pattern and their life style.

Juni (2014) investigated effects of global media on Pakistani culture and indicated that youth is regular viewer of Cable TV. They watch global media mostly for entertainment and time pass. Young people learn about new cultural trends presented in TV programs and also practice these cultural trends. The youngsters prefer to wear western dresses casually and also on festivals. They prefer eating fast food, celebrating international days, and speaking foreign languages such as English and Hindi. Foreign TV channels are promoting western customs and values which are often contradictory to local cultural and religious standards.

In a study, Aslam, Ali, Faiz-ullah, and Munawar (2015) examined impact of foreign TV program (Turkish drama) on educated Pakistani females. He reported that Turkish drama has huge 
viewership and popular segment of entertainment industry despite of bold and controversial content. Exposure to such foreign content is affecting our social relationships especially institutions of marriage and family.

Hossin and Mohiuddin (2015) studied impact of global media on youth and found that global media has great impact on people who are exposed to it. Youth culture of Bangladesh is being diffused with western culture. Young generation favors fashionable clothes, fast food, western family and marriage style, western music, films and festivals. They have gained their own uniqueculture within food, dressing, entertainment, etc. Global media through infusion of foreign culture has created a particular youth culture.

Bhatti, Gondal, Sheikh, Hammad, and Zafar (2016) investigated impact of foreign media on Pakistani youth and found that major purpose of watching foreign media among youth is entertainment. Youth liked Indian and Western programs more than local programs and watch them frequently which influence various aspects of their culture. Young people like to wear western dresses, to follow new fashion and to celebrate Indian and western festivals. Foreign media is promoting culture that is against local cultural and religious values.

Ali and Yusaf (2017) examined relationship between TV commercials and changing lifestyle of youth and Normative structure of Pakistani society. Youth is greatly inspired by TV advertisements and content presented in them strongly influence their food and eating habits, dressing style and appearance, purchasing habits, and their total lifestyle. Besides, TV commercials are changing strands of normative structure and promoting adoption of foreign cultures.

Muhiuddin, Zuberi, Khan, and Khan (2018) described that Indian advertisements on Cable TV are adversely affecting youth in Pakistan. Most of youth watch television 2-6 hours daily and they are frequent viewer of Indian advertisements. Due to this frequent exposure, Indian culture is spreading rapidly and replacing local cultural values and traditions. The pervasive impacts includes learning Hindi language and adoption of Indian and western dressing style.

Shafayat(2019) concluded that media play a very vital role in the growth and protection of our society's social and cultural values. Television plays a major role in cultural transmission. More specific television has become in this new era a significant and future source of mass communication.

\section{METHODOLOGY}

Descriptive Survey method was used for this study. The study was conducted in Tribal area of Dera Ghazi Khan, Punjab, Pakistan. The data was collected through a research survey and multistage sampling technique was used. At first stage, 6 out of 9 union councils were selected randomly from tehsil tribal area, at second stage, 3 villages were selected randomly from each union council, at third stage, 23 respondents aged 15 and more, using global factor were selected purposively from each village. A structured interview schedulewas used for data collection as research instrument based on5 point Likert scale. Interview schedule consisted of multiple questions structured in three sections. The first section contained information related to socio-economic characteristics of respondents, the second section was related to the exposure of tribal people to global factors (radio, satellite TV and internet) and third section was about tribal cultural values and social relationships. Total 420 respondents were interviewed for purpose of data collection. The data was analyzed through SPSS Version 26.

RESEARCH HYPOTHESIS 
To meet research objectives, following hypothesis was formulated:

1. More the global media usage, more will be adoption of foreign cultural traits.

2. Younger the age, higher will be adoption of foreign cultural traits.

\section{RESULTS AND DISCUSSION}

The main objective of the present research was to find out the effects of global media on tribal culture in Dera Ghazi Khan, Punjab.According to the objectives, the exposure of tribal people towards global media is to be first discussed but for reader's familiarity towards the characteristics of Tribal Community, the SocioEconomic characteristics are discussed before it.

\section{Socio-economic characteristics}

Table 1: Distribution of the respondent's by Age

\begin{tabular}{|c|c|c|}
\hline Age Categories & Frequency & Percent \\
\hline 15 to 24 Years & 114 & 27.1 \\
\hline 25 to 34 Years & 161 & 38.3 \\
\hline 35 to 44 years & 91 & 21.7 \\
\hline 45 Years and Above & 54 & 12.9 \\
\hline Total & 420 & 100.0 \\
\hline Mean & \multicolumn{2}{|c|}{ 27 years } \\
\hline
\end{tabular}

In Table 1. respondents were divided into age wise categories. The maximum (38.3\%) respondents were from the age bracket of 25 to 34 years. The (27.1\%) of the respondents were from the age bracket of 15 to 24 years, $(21.7 \%)$ were from the age bracket of 35 to 44 years and remaining (12.9\%) were of 45 years and above age. This shows that majority $(65.4 \%)$ of the respondents fall in the age bracket of 15 to 34 years which means they were mostly young. The mean of the age category was 27 years.

Table 2: Distribution of the respondent's by

\section{Educational Level}

\begin{tabular}{|c|c|c|}
\hline $\begin{array}{c}\text { Educational } \\
\text { Level }\end{array}$ & Frequency & Percent \\
\hline Illiterate & 85 & 20.2 \\
\hline Primary & 92 & 21.9 \\
\hline Middle & 85 & 20.2 \\
\hline Matric & 90 & 21.4 \\
\hline Intermediate & 34 & 8.1 \\
\hline Graduation & 13 & 3.1 \\
\hline Masters & 17 & 4.0 \\
\hline Above Masters & 4 & 1.0 \\
\hline Total & 420 & 100.0 \\
\hline Mean & \multicolumn{2}{|c}{ Middle } \\
\hline
\end{tabular}

To observe the educational level of the respondents, data was gathered and presented in Table 2. The data showed that $(20.2 \%)$ of the respondents were illiterate, they never went to school to get formal education. The majority $(63.5 \%)$ of respondent's educational levels were between Primary to Matric, they went to school which depicts that because of globalization, people are becoming aware and getting interest in school education. The remaining other $(16.3 \%)$ respondents attained educational level from Intermediate to Masters and above. The mean of the educational level was Middle.

Table 3: Distribution of the respondents regarding Family Income (Per Month)

\begin{tabular}{|c|c|c|}
\hline $\begin{array}{c}\text { Family Income (Per } \\
\text { Month) }\end{array}$ & Frequency & Percent \\
\hline Up to 9999 Rs. & 99 & 23.6 \\
\hline 10,000 to 24,999 Rs. & 197 & 46.9 \\
\hline 25,000 to 39,999 Rs. & 71 & 16.9 \\
\hline 40,000 to 54,999 Rs. & 29 & 6.9 \\
\hline 55,000 Rs. \& Above & 24 & 5.7 \\
\hline
\end{tabular}




\begin{tabular}{|c|c|c|}
\hline Total & 420 & 100.0 \\
\hline Mean & \multicolumn{2}{|c|}{ 28000 Rs. } \\
\hline
\end{tabular}

Income is a major factor in defining the socioeconomic status of any individual. So data was gathered to know the financial status of the respondent. This table 3. describes the distribution of respondents regarding their family income (Per Month). The majority (46.9\%) of the respondents had family income (Per Month) in the category of $(10,000$ to
24,999) PKR, the (23.6\%) of the respondents had family income (Per Month) in Category of (up to 9999) PKR, (16.9\%) of the respondents had family income (Per Month) in category of (25000 to 39,999) PKR, the $(6.9 \%)$ Respondents fall in the category of $(40,000$ to 54,000$)$ PKR and the remaining (5.7\%) belonged to the category of $(55,000 \&$ Above) PKR. The mean of the family income (per month) was 28000 Rs.

Table 4: $\quad$ Correlation Coefficient Matrix

\begin{tabular}{|c|c|c|c|c|c|c|}
\hline \multirow{2}{*}{ Variables } & $\begin{array}{c}\text { Spearman's } \\
\text { Correlations }\end{array}$ & $\begin{array}{c}\text { Global Media } \\
\text { Usage }\end{array}$ & Age & $\begin{array}{c}\text { Foreign } \\
\text { Languages }\end{array}$ & $\begin{array}{c}\text { Foreign } \\
\text { Dress }\end{array}$ & $\begin{array}{c}\text { Foreign } \\
\text { Food }\end{array}$ \\
\hline \multirow{2}{*}{$\begin{array}{c}\text { Global Media } \\
\text { Usage }\end{array}$} & $\begin{array}{c}\text { Correlation } \\
\text { Coefficient }\end{array}$ & 1.000 & $-.188^{* *}$ & $.144^{* *}$ & $.109^{*}$ & $.213^{* *}$ \\
\cline { 2 - 7 } Aig. (2-tailed) & & .000 & .003 & .026 & .000 \\
\hline \multirow{2}{*}{ Age } & $\begin{array}{c}\text { Correlation } \\
\text { Coefficient }\end{array}$ & $-.188^{* *}$ & 1.000 & -.070 & $-.198^{* *}$ & $-.108^{*}$ \\
\cline { 2 - 7 } Language & Sig. (2-tailed) & .000 & & .152 & .000 & .028 \\
\cline { 2 - 8 } & $\begin{array}{c}\text { Correlation } \\
\text { Coefficient }\end{array}$ & $.144^{* *}$ & -.070 & 1.000 & $.285^{* *}$ & $.192^{* *}$ \\
\hline \multirow{2}{*}{ Foreign Dress $(2-$ tailed) } & .003 & .152 & & .000 & .000 \\
\cline { 2 - 8 } & $\begin{array}{c}\text { Correlation } \\
\text { Coefficient }\end{array}$ & $.109^{*}$ & $-.198^{* *}$ & $.285^{* *}$ & 1.000 & $.194^{* *}$ \\
\hline \multirow{2}{*}{ Foreign Food (2-tailed) } & .026 & .000 & .000 & & .000 \\
\cline { 2 - 8 } & $\begin{array}{c}\text { Correlation } \\
\text { Coefficient }\end{array}$ & $.213^{* *}$ & $-.108^{*}$ & $.192^{* *}$ & $.194^{* *}$ & 1.000 \\
\cline { 2 - 8 } & Sig. (2-tailed) & .000 & .028 & .000 & .000 & \\
\hline
\end{tabular}

**. Correlation is significant at the 0.01 level (2-tailed)

*. Correlation is significant at the 0.05 level (2-tailed)

Table 4 shows relationship of age and global media usage with adoption of foreign cultural traits. The results show that age had negative $\left(-0.188^{* *}\right)$ and highly significant (0.000) correlation with global media usage which indicates that the tribal people who are young, are more likely to use global media than the older ones. Moreover, age had a negative (-0.070) and non-significant (0.152) correlation with learning foreign languages which means that the age causes very little difference in learning foreign languages, but the age had negative $(-0.198 *)$ and highly significant (0.000) relationship with wearing foreign dresses. It entails that young tribal people were more likely to wear foreign dresses. Similarly, relationship between age and eating foreign food had negative $(-0.108 *)$ and significant $(0.028)$ correlation. Which indicates that www.psychologyandeducation.net 
the young tribal people like to eat foreign food more. To encapsulate, the younger tribal people were more likely to learn foreign languages, wear foreign dresses and eating foreign food, means that they were more likely to adopt foreign cultural traits. These results are consistent with previous studies as Muhiuddin, Zuberi, Khan, and Khan (2018) described thatyouth watched television 2-6 hours daily and they are frequent viewer of Indian advertisements. Due to this frequent exposure, Indian culture is spreading rapidly and replacing the local cultural values and traditions. SimilarlyNaseer, Nawaz, Azhar, et al. (2014) identified that International media is playing vital role in influencing cultural valuesamong Pakistani youth.They learn foreign languages, dressing styles, cuisine, music, values and cultural patterns. In another study, Juni (2014) investigated effects of global media on Pakistani culture and indicated that youth is regular viewer of Cable TV.Young people learn about new cultural trends presented in TV programs and also practice these cultural trends.

The relationship of global media usage and learning foreign languageswas positive $(0.144 * *)$ andhighly significant (0.003), which explains that people who use global media more, are more likely to learn foreign languages.The Global media usage had positive $(0.109 *)$ and significant (0.026) correlation with wearing the foreign dresses. It entails that people who use global media more, are more likely to wear foreign dresses.The relationship between global media usage and eating foreign food was positive $\left(0.213^{* *}\right)$ and highly significant $\quad(0.000)$ which indicates that tribal people who use more global media are more likely to eat foreign food. To sum, people who use global media more, are more likely to learn foreign languages, wear foreign dresses and eating foreign food. These results were consistent with Bhatti,
Gondal, Sheikh, Hammad, and Zafar,(2016) found that major purpose of watching foreign media among Pakistani youth is entertainment. Young people like to wear western dresses, to follow new fashion and to celebrate Indian and western festivals. Foreign media is promoting culture that is against local cultural and religious values. In another study, Hossin and Mohiuddin (2015) concluded that global media has great impact on people who are exposed to it. Young Bengali generation favors fashionable clothes, fast food, western family and marriage style, western music, films and festivals. They have gained their own uniquepersonalitieswithin food, dressing, entertainment, etc.

\section{CONCLUSION}

The tribal people mostly belong to low socioeconomic status, but they were fond of using global media. The young tribal people were heavy users of global media and they had more inclination to adopt foreign cultural traits such as learning foreign languages, wearing foreign dresses and eating foreign food. Older tribal people had strong integration with tribal cultural values and had more social ties with local tribal community. Global media was being prevalent in tribal area causing change in tribal culture and weakening people's relationships with local tribal community.

\section{REFERENCES}

Ahuja, B.N., \& Batra, S. (1978). Mass Communication (Press, Radio, TV, Films, Advertising and other Media). New Delhi: Verma Brothers.

Ali, S., \&Yusaf, Z. (2017). Impact of TV Advertisement on changing lifestyle of the youth and how TV advertisements affect the norms and values of the society. Global Media Journal, 10(2), 1-25. 
Appadurai, A. (1990). Disjuncture and Difference in the Global Cultural Economy. Public Culture, 2(2), 1-24.

Aslam, S., Ali, A., Ullah, F., \& Munawar, M. (2015).Socio-Ethical Impact of Turkish Dramas on Educated Females of GujranwalaPakistan. Journal of Humanities and Social Science, 20(2), 125-131.

Bhatti, M., Gondal, M., Sheikh, M., Hammad, A., \& Zafar, F. (2016). Negative Effects of Mass Media and the Dominance of Foreign Culture in the City of Lahore, Pakistan. American Scientific Research Journal for Engineering, Technology, and Sciences, 26(3), 244-253.

Castells, M. (2001). Internet Galaxy: Reflections on the Internet, Business and Society. New York: Oxford University Press.

Cleveland, M., \& Laroche, M. (2007). Acculturation to the global consumer culture: Scale development and research paradigm. Journal of business research, 60(3), 249-259.

Hofstede, G. (1984). Culture's consequences: international differences in work-related values. London: Sage Publications.

Hossin, M. Z., \& Mohiuddin, M. (2015). Urban Youth Culture in Bangladesh under the Sway of Cultural Globalization: A Descriptive Analysis. Sociology Mind, 5(1), 213226.http://dx.doi.org/10.4236/sm.2015.53019

Juni, M. S. (2014). Impact of Global Media on the Culture of Pakistan: A Case Study of Youth of Layyah City. International Journal of Innovation and Applied Studies, 8(3), 10081014.

Kluver, R., \& Fu, W. (2004). The cultural globalization index. In Foreign Policy Magazine. Retrieved from https://foreignpolicy.com/2004/02/10/the-

cultural-globalization-index/

Morris, M. W., Mok, A., \&Mor, S. (2011). Cultural identity threat: The role of cultural identifications in moderating closure responses to foreign cultural inflow. Journal of Social Issues, 67(4), 760-773.

Muhiuddin, Z.A., Zuberi, I. Z., Khan, S.F., \& Khan, S. F. (2018). Adverse Effects of Indian Television Advertisements on Youth's Cultural and Social Values in Pakistan. International Journal of Scientific \& Engineering Research Volume, 9(11), 359365.

Naseer, M., Nawaz, Y., Azhar, Z., Andleeb, Z., Ahmad, U., \& Riaz, F. (2014). A Sociological Analysis of Cultural Imperialism of International Media on Pakistani Youth. Mediterranean Journal of Social Sciences, 5(3), 523-532.

Qamar, M., Asim, M., Shawar, D., \& Zafar, M. I. (2012). The impacts assessment of Indian culture on Pakistani society in Faisalabad. International Journal of Research in Social Sciences and Humanities, 1(5), 53-62.

Roosens, E. (1995). Interest groups with a noble face. In J. A. Costa, \& G. J. Bamossy (Eds.), Marketing in a multicultural world (pp. 126141). Newbury Park: Sage publications.

Schiller, H. I. (1969). Mass Communication and American Empire. Boston, MA: Beacon Press.

Shafayat, A. (2019). Effects of TV commercials on socio-cultural norms: An analysis of viewers' perceptions (unpublished doctoral dissertation). University of Gujrat, Pakistan.

Sultana, N. (2007). The role of media in the development and promotion of English in 
Pakistan (unpublished doctoral dissertation).

National University of Modern Languages, Islamabad.

Verma, S. C. (2008). The Changing BUXA Culture: A Study of Indian tribe in Cultural Dynamics. (Typescript). Government postgraduate college, India. Retrieved from http://images.gmanews.tv/pdf/aseanconf/VER MA\%20 Subash.pdf

Wang, Y. (2007). Globalization enhances cultural identity. Intercultural Communication

Studies, 16(1), 83-86. 